aggerated reparation payments and a breathing interval for at least a number of years in which no payments ought to be made at all. Added to that must be a considerable loan, in which Ger- many hopes that the United States will take part, for it seems that a collapse of Germany and consequently of other European nations is inevitable if the United States continues to stand aside.

\title{
Possibilities of the Economic and Financial Reconstruction of Austria
}

\author{
By Edgar L. G. Prochnik \\ Charge d 'Affaires of Austria
}

$\mathrm{T}$ WE present state of affairs in Austria is the natural outcome of the liquidation of the world's greatest war, a liquidation which responsible persons on both sides of the former contesting parties have by now realized and openly admitted to be a great failure, one of the greatest mistakes ever made in history. While all Europe has, as a matter of course, to bear for some time to come the disastrous consequences naturally emanating from a war of such dimensions and duration, Austria, in particular, was burdened with additional weights, so ponderous that they would have crushed even a strong and flourishing country just emerging from a period marked by a normal and prosperous development of its economics. Austria was expected to shoulder this burden at a time, when a protracted war, during which she was hermetically shut out from contact with the outer world, had entirely depleted her resources. When the war closed, there was no food, no coal, no raw materials in the country and the system of communication was at a breakdown. Austria, emerging from the war a bleeding, mangled body, was expected immediately to rearrange her whole economic structure, to transform herself by magic power from a self-supporting country into one that could secure a livelihood for its population only through an extensive production and export, and this at a moment when there was hardly any means of production left in the country, and no solvent buyer stirring abroad.

Economic Effects of New BoundARIES

Austria's financial troubles first started with the fixing of her boundaries. She has, indeed, the rare but sad distinction of being a country without boundaries, i. e., without natural, or ethnographic, or economic boundaries, suggesting in her outlines rather the tracings of a youngster who was left on a highchair playing with a map of Europe and some colored pencils, than the cartographic reproduction of a geographical unit.

Her troubles started, moreover, with the total lack of any plans which might have been adopted in order to mitigate, as much as possible, the disastrous results of the political dismemberment of the former AustroHungarian Monarchy, on the delicate structure of its economics. It was this total disregard of the economic interests, manifested, for instance, in the nostrification of the notes of the former Austro-Hungarian Bank by the various countries which were created by the dismemberment of the former Dual Monarchy or to which territory of 
said empire was transferred, that sent the Austrian currency tumbling down. The way in which the liquidation of the former Austro-Hungarian Monarchy was transacted, could be justly likened to a settlement of an estate in probate or bankruptcy proceedings, which should open with a decree of final distribution, followed, six months after enforcement of this decree, by an order to ascertain the assets and liabilities involved.

Austria suddenly found her whole industrial machinery thrown into hopeless confusion. Entire branches of industry were technically dismembered, a process of dissolution which affected even individual corporations. Cotton manufacturing concerns, for instance, found their spindles separated from the looms, the looms from the finishing plants and place of distribution. Almost insurmountable obstacles suddenly arose in the form of boundaries between steel manufacturing plants and the mines which used to supply them with coal and ore. The same state of affairs uprooted the whole system of trading and banking, the main offices being unable to get in touch or to transact business with their branch offices and affiliated companies.

New boundaries dissected the railroads, regardless of system, leaving whole sections without terminals, points of junction, roundhouses or repair shops, and crippling traffic in Central Europe almost beyond any possibility of repair. The natural consequence was a tariff war between the Succession States waged with such intensity as the world has never before experienced.

These were the general causes from which grew the present financial conditions of Austria. They are not mentioned here with any intention to bewail spilled milk, or with any desire to prolong useless criticism of past events, which cannot be undone. If the author has dwelt somewhat lengthily on this painful subject, he was prompted to do so by the belief and hope that almost all nations, neutrals as well as those directly concerned in the last big strife, are beginning to realize that Europe, nay the whole world, cannot be brought back to normal conditions unless they all pick up sufficient courage to attack the malady at its core, and to sound the wound as deeply as they can possibly stand the pains.

\section{The Food Problem}

The signing of the Armistice, as you know, did not mean for Austria the end of her sufferings. The grim work of the Reaper did not cease when the Austrian people laid down their arms. Death, it is true, no longer looked for its victims on the battlefields, but invaded the peaceful homes of the Austrian people, where women and children and the aged, weakened by long privations, fell an easy prey to the merciless strokes of his scythe. Austria had to face a most difficult food problem, which was another factor, or rather, the main reason for the disorder into which the Austrian finances were thrown. This food problem made it impossible to establish even the semblance of a budget. I am well aware of the fact that the ways in which this problem was handled met with criticism from many sides, especially from those who believed in abolition of food control by the government. I think, however, that the future will acknowledge the wisdom of this measure, as in the first years after the Armistice a free trade in food supplies would undoubtedly have meant starvation for at least two-thirds of the population, unable to cope with the skyward move of the prices. I hardly believe that in the first twenty-four months after the 
War private concerns could have obtained the necessary food supplies through purchase abroad.

But the mere fact that Austria had to buy food abroad, i. e., to pay with gold-edged securities, must needs have a depreciating effect on her currency, since there was no means of counterbalancing this ever-increasing liability by an halfway adequate export. The more food was bought, the larger grew the margin between the Austrian kronen and the gold standard; and the more the Austrian kronen sank in its purchasing power, the faster the note press had to work. The Austrian government and its advisers well knew that salvation could not be found in keeping the printing presses well greased and running at full capacity, but, in the absence of other efficient ways and means of replacing this faulty system, it had to be kept up, in order to prevent a general breakdown accompanied by starvation and all kinds of political and social upheavals.

As you may know, the system of selling bread and flour to the people at a cost far below the purchasing price created an ever-growing deficit, which threw the budget into disorder and made futile any effort to bring about some semblance of a balance between revenues and expenditures. This system has since been abandoned, but not very much was gained thereby, as wages and salaries had to be accordingly increased to enable the employes to keep pace with the skyward move of the cost of living. People engaged in trade, agricultural production, or manufacturing of goods, automatically raise their earnings with the increasing cost of living and, vice versa, increase the cost of living by their constant demand for higher wages. The whole brunt of the catastrophe is, therefore, weighing on that class of the Austrian population which derives its means of livelihood from fixed salaries, pensions, rents, interest on savings account, and remuneration for professional services and intellectual work. This class of the population, crowded together in the cities, particularly in Vienna, and falsely and unjustly styled the unproductive class, offers under the present state of affairs one of the most trying problems in the solution of Austrian financial difficulties.

\section{Government Employes}

We have repeatedly heard in the last few years the slogan: "Away with the many government employes, for what does a country as small and poor as Austria need with so many officials, who merely are unproductive consumers?" This battle cry, invented by somebody in the crowd, has been thoughtlessly picked up and sung in many variations. A census of government employes was given out, and the stupendous figure of over 200,000 , nay almost 250,000 was named, and compared with those of bigger countries, where not nearly as many people are employed in the public machinery. The government of Austria was urged to reduce the number of government employes, and, in the hope of cutting the expenditures, actually took up the problem of demobilization of the public workers.

But soon the fallacy of the exaggerated statements became apparent. People had overlooked the fact, that over 60 per cent of these state employes are engaged in the operation of railroads, telegraphs and telephones, which means of public utilities are, as you know, managed in Austria by the government. Such people would not be called officials if the railroads, telegraphs and telephones were operated by private concerns as in many other countries. All the judiciary apparatus is governmental; the greater part of 
the personnel engaged in public education, i. e., the teachers and professors in the high schools and universities, are government officials. There are industrial enterprises (the salt and tobacco monopolies for instance) in which the government is concerned and the people engaged therein are called officials. Furthermore, a vast extent of public forests is taken care of by government foresters. There is, also, the small but costly army with which against her wish and will Austria was presented by the signatories of the Peace Treaty of St. Germain. Finally, included in the stated number of officials are the state police and constabulary and so forth. If all these persons were dropped from the list of civil service, there would remain a comparatively small number of officials in the proper sense of the word, too small to have a bearing on the problem in question, even were reduction to be carried out to a degree of entire abolition of the whole apparatus of public administration.

The inflation of paper money, the sinking of the exchange value of the Austrian kronen, cannot be remedied by mere cut of expenditures in the budget and by increase of the state revenues. The taxes have been and still are considerably increased. The rates of public utilities have reached prohibitive heights. What is the result? The people need more and more paper money, and the government receives in its coffers mountains of money, which it has manufactured only shortly before.

Austria may through internal measures and her own efforts contribute to some small degree toward her economic and financial reconstruction, but the most essential aid is the help from outside, in form of credits. I am convinced that no one of the signatories of the Peace Treaty of St.
Germain believed for a moment, at the time of the signing of that document, that without this financial help Austria could maintain an independent existence.

\section{Credit, the Keystone of the Situation}

The whole question of the rehabilitation of Austrian finances hinges on credit. To enable the realization of such credit, Austria will have to pledge her assets which were, or at present still are, encumbered by claims of various countries secured partly under the title of reparations, partly under the title of relief. All these claims have to be deferred, and, as is well known, the United States of America has only recently, in that true spirit of generosity so traditionally characteristic of all acts of this great nation, come to the assistance of Austria and blasted a way toward the country's rehabilitation. I refer to the Joint Resolution recently passed by Congress and signed by the President, which, under certain justified reservations, empowers the government of the United States to defer certain liens held against the Austrian assets.

Credit is a matter of confidence, not only in the political and social stability of a country but also in its possibilities for a favorable economic development. As far as social and political stability is concerned, I do not think that any apprehension can still exist today in regard to Austria. Austria had to maintain her equilibrium in worse times, when the waves of most reactionary social perturbations were surging and tossing against her boundaries. All careful observers of the conditions in Austria must admit that this country offered a barren soil to revolutionary sowing. Yet the Austrian people in overwhelming majority would not support any move which 
would lead to any unfavorable reaction. They are most desirous to work out in peace the difficult economic problem facing them. The government, in fact all the governments in force there since the conclusion of peace, is guided by the unshakable conviction that Austria has strictly to adhere to obligations imposed on, and accepted by her, with the signing of the St. Germain Treaty.

This principle is the keystone on which Austria's policy is built up. Austria realizes that she must maintain this attitude for mere self-defence, if for no other reasons. The Austrians do not think for a moment of shouldering responsibilities for a failure in compliance with assumed obligations, only to be blamed, when matters do not come out as is generally hoped. Austria has within the last two years in her legislative measures placed her whole internal structure in conformity with these obligations. She has never opposed herself to the demands and requirements made by the powers, and has in this respect in some cases gone even so far as to swallow her national pride, and tolerate infringements on her sovereign rights.

This loyal attitude deserves consideration. With some leniency in the execution of the treaty provisions, especially in the economic and financial clauses, the financial difficulties of Austria could be considerablyalleviated and her credit strengthened. It is essential for the rehabilitation of Austria that she finally cease to be regarded as the successor of the former Austrian Empire, burdened with fateful inheritance. There is no reason why she should not, like the other Succession States, be treated as a new republic recently arisen from the dismemberment of the Dual Monarchy. The outlook for her future would at once assume a brighter aspect.

\section{Possibilities of Credit}

Hand in hand with the efforts to secure adequate credit should go a tendency to establish a wider base for this credit. Austria alone may be too small to offer a broad enough base for an extensive rehabilitation plan, or sufficient securities for a credit operation on a large scale. She must needs be inserted into a bigger economic body. As she is not permitted to form a union with Germany, she must at least look for an economic attachment among her neighbors. The most natural thing is an economic approach to those countries which once formed with her the Dual Monarchy, as there undoubtedly exists an economic affinity between them, even if the justification for a political union or confederation has been disapproved by the latest events. This necessity has already made itself felt, not only in Austria but also in the neighboring countries. A considerable step forward has been made in the Conference of Rome and Portorose. Matters cannot be rushed, but the results achieved there are greater than generally realized in America.

The two most industrially progressive parts of former Austria-Hungary, Czechoslovakia and Austria, for instance, have already found a way to overcome their differences, and to establish closer ties in their mutual economic relations. They have thus formed a nucleus which will irresistibly draw other neighboring countries into a knot of common economic interests. I see before me a gradual expansion towards east and west of this economic affiliation, regardless and in spite of politicalboundaries. Modern economic developments are fast teaching us to forget our atavistic tendency to see in political boundaries the confines of common interests. 
I therefore believe that the economic and financial rehabilitation of Austria will best be effected by being included in a general systematic plan, embracing the reconstruction of whole Europe. And I furthermore believe that this much-talked-of credit should be raised and distributed among the needy countries only in conformity with this systematic plan of mutual economic coöperation, if the invested funds are to be properly insured.

And now, you will ask me, what will be attained in Austria with credit? All financial experts agree that the first step to be made is the stabilization of the currency, or better, the rate of exchange. I shall not enter into details in regard tothe solution of this problem, as this is reserved for the world's greatest financial authorities. The next purpose of credit is to help to bring Austria's natural resources to better account: to increase her agricultural capacity, thus reducing a great item on the debit side of her trade balance; to exploit her vast supply of heretofore undeveloped water power, thus eliminating the tremendous costs of her coal imports, and to revive industrial production, export and so forth.

\section{Austrin's Securities}

What are Austria's assets, the securities she is able to offer? The answer is, her natural resources and the labor of her population. These are the working capital left to Austria with which to build up her future. Austria's existence will be secured at the moment she is able to counterbalance by trade the deficit in her food supplies. Austria will never be able to grow all her supplies within her own boundaries. I am aware of contrary opinions, substantiated by statistical figures. A careful examination of them, however, reveals errors, as, for instance, figuring on a base of war rations, or neglect in allowing for seeding and waste in milling. I think that even under the most favorable conditions 25 per cent, at least, of the country's needed food supplies will have to be secured from abroad. Now this means a heavy item on the debit side of its trade balance. Austria's trade and industry, however, could be slowly and gradually stretched to cover this liability.

I shall briefly point out the possibilities. Austria has an old, established andfar-advanced steel industry, offering great opportunities for further expansion; she has a paper industry capable of producing twice the quantity needed for home consumption; her woodworking industry is utilized far below capacity. The same is the case with the chemical industry. In this connection I must not forget the leather industry, especially the manufacture of fancy goods, in which Austria and Vienna in particular take a leading place. All these industries will be greatly benefited by a gradual exploitation of the two millions $H$. P. of as yet undeveloped water power. There are, moreover, the Austrian Alps, conducive as the Swiss Alps, to cattle raising on a large scale, and the manufacture of dairy products.

One of the greatest assets of Austria, however, is her geographical location. Austria, in particular her capital, is the natural exchange for the trade between the western countries and the Near-East and Russia, and for the transit from north to south. Vienna has not attained her importance through artificial means, but has developed naturally to her present position as one of Europe's most important capitals, on strength of her location. It would take me too long to dwell on the importance of Vienna as a central junction of the main lines of Europe's railway-system and as the greatest harbor on the 
Danube, where goods flow in through easy channels of communication and can find an easy and cheap way to further distribution into the Balkan countries and the shores of the Black Sea. Due to this fortunate location a particular branch of jobbing has for many generations established itself in Vienna, specializing in the eastern trade and generally recognized as unsurpassed in its efficiency. This plan of developing Vienna into one of the most important jobbers of Europe is deserving of due consideration. When we look closer to the chances and possibilities of Austria's future, things look at once bright and cheerful. All Austria needs in order to effect this necessary transformation of her economics, is assistance in developing her resources. In other words, she needs credit, and only credit can save her. She must be carried over the time which is needed to rearrange her whole economic structure. England, France, Italy and Czechoslovakia have, as you know, recently come to her assistance with advance credits, the forerunner, it is hoped, of the great systematic plan of rehabilitation.

\section{Participation of America}

But one dark spot on the horizon is the absence of the United States of America from among the powers planning the reconstruction of Europe. It does not behoove me to comment on the advisability or non-advisability of America's active participation in this work under present circumstances. I do wish, however, to voice a general hope that the time is near when the events and conditions in Europe will so shape themselves that the wise leaders of America will consider the proper moment come to ascend the steps leading to the supreme bench reserved to the "arbiter mundi." This wish is expressed in consciousness of the great moral influence which such a decision would have on the whole world, for there is undoubtedly no power on earth, which with a clearer conscience could take over this exalted function of a Righter of the World, as the United States of America, fully impartial to all kinds of petty jealousies and selfish reasons, and partial only to the welfare and interests of mankind, justice and genuine lasting peace.

\title{
The Industrial and Financial Situation in Great Britain and Its Remedies
}

\author{
By John Joyce Broderick \\ Commercial Counsellor, British Embassy
}

$\mathrm{T}$ WE fundamentals of the British position, fortunately, are very simple. They scarcely need to be stated, much less to be examined in detail, especially since the important events and movements which take place in England are generally very fully reported in the American press and followed by the American business public almost as closely as the situation in the United States itself. However, it is sometimes useful to restate fundamental facts, especially when you are considering remedies for existing evils, or endeavoring to find ways and means of meeting difficulties with which you are confronted, and that must be my excuse if $I$ should appear to be too elementary in what I say.

An official estimate made a little before the outbreak of the European War indicated that we had in Great 